\title{
PENGARUH PRODUCT QUALITY, CELEBRITY ENDORSER DAN SALES PROMOTION TERHADAP KEPUTUSAN PEMBELIAN SEPATU ADIDAS PADA WILAYAH TANGERANG SELATAN
}

\author{
Bonar Frans Sihite \\ Staf Pengajar Fakultas Ekonomi Universitas Pamulang \\ Email: bonarfranss@yahoo.com
}

\begin{abstract}
ABSTRAK
Tujuan dari penelitian ini adalah "Untuk meengetahui penngaruh anatara product quality terhadap keputusan pembelian, untuk mengetahui penngaruh anataraa celebrity endorser terhadap keputusan pembelian, untukk menggetahui penngaruh anataraa sales promotion terhadap keputusan pembelian, untuk mengetahui pengaruh seacara simultan antara product quality, celebrity endorser dan sales promotion terhadap keputusan pembelian.".

Penelitian ini menggunakan data primer yang didapat berdasarkan hasil jawaban responden melalui penyebaran kuesioner kepada pengguna sepatu Adidas. Sampel dalam penelitian ini adalah sebanyak 60 responden. Hasil penelitian menunjukkan bahwa terdapat pengaruh secara parsial antara product quality, celebrity endorser dan sales promotion.

Hasil penelitian ini juga menunjukkan bahwa product quality, celebrity endorser dan sales promotion berpengaruh terhadap keputusan pembelian secara bersama-sama (simultan). "Pada koefisien determinasi terdapat pengaruh sebesar 82,7\% yang mempengaruhi keputusan pembelian yang dijelaskan oleh variable product quality, celebrity endorser dan sales promotion, sedangkan sisanya $17,3 \%$ dipengaruhi oleh variabel lain yang tidak terdapat dalam penelitian ini".
\end{abstract}

Kata kunci: product quality, celebrity endorser, sales promotion, keputusan pembelian.

\section{ABSTRACT}

"The purpose of this research is "to meengetahui penngaruh product description quality against the purchasing decision, to know the penngaruh anataraa celebrity endorser of purchase, for the Bundesliga menggetahui penngaruh anataraa sales promotion against the purchasing decision, to know the influence of simultaneous seacara between product quality, celebrity endorser and sales promotion towards purchasing decision". The research of using primary data obtained based on the answers of the respondents through the dissemination of questionnaires to users of Adidas shoes. The sample in this research is as much as 60 respondents. The results showed that there was a partial influence between product quality, celebrity endorser and sales promotion. The results of this research also shows that product quality, celebrity endorser and sales promotion effect on purchasing decisions simultaneously (simultaneous). "There is determination of the coefficients On the influence of $82.7 \%$ that affect purchasing decisions are explained by the variable product quality, celebrity endorser and sales promotion, while the remaining $17.3 \%$ is affected by other variables that are not There is in this research ".

Keywords: product quality, celebrity endorser, sales promotion, purchase decisions

\section{PENDAhluan}

\section{A. Lataar Beelakang Penelitian}

"Kebutuhan yang berkembang saat ini adalah sepatu, sebagai salah satu barang penunjang fashion, keberadaan 
sebuah sepatu ternyata mulai diminati sebagian besar masyarakat. Bila dulunya sepatu hanya dibutuhkan para pelajar ketika pergi ke sekolah ataupun para pekerja kantoran yang selalu terlihat necis dengan tampilan sepatu pantofelnya. Sekarang ini kebutuhan sepatu mulai mewabah ke berbagai kalangan masyarakat dengan menampilkan berbagai macam bentuk atau model yang menarik, serta pilihan warna yang cukup beragam. Asosiasi Persepatuan Indonesia (Aprisindo) memprediksikan kalau dua prinsipal asing pada akhir Oktober ini akan menambah ordernya hingga 20\% untuk pengiriman ekspor pada awal tahun depan 2014".

Salah satu syarikat pengeluar kasut terkenal dari Jerman ialah Adidas, juga menghasilkan kasut futsal dengan jenama ADIDAS . Adidas adalah jenama terkemuka di dunia, ramai atlet dunia juga menggunakan kasut Adidas. Adidas diasaskan di bandar Herzogenaurach, Jerman pada tahun 1920 oleh dua adik lelaki Adolf (Adi) Dassler dan Rudolph Dassler di dalam bilik dobi ibunya. Pada masa itu Adi Dassler membuat projek kecil dengan membuat kasut sukan. Kerana kasut yang berkualiti tinggi ia menghasilkan, akhirnya perniagaan kecil mula membayar. Pada tahun 1924, Adi Dassler dan saudaranya Rudolf Dassler mengasaskan 'Dassler Brothers OGH' yang kemudiannya menjadi pelopor (http://www.catatansejarah.com).
Pada 2012, Adidas menerima Anugerah Jenama Terunggul 2012 untuk kategori Kasut Sukan Terbaik. Demi kepuasan pelanggan, Adidas berusaha mengembangkan produknya dan membuat inovasi baru melalui kasut terbaru. Di peringkat persaingan produk yang sangat kompetitif, pengguna akan sangat selektif apabila membeli produk dengan melihat harga, jenis, dan jenama produk itu sendiri .

Prestasi yang dicapai Adidas sebagai sepatu yang memiliki merek terkenal, bahkan menjadi top brand disebabkan karena konsumen yang meningkat dan diukur berdasarkan jumlah konsumenya. Untuk mempertahankan itu semua perusahaan harus meningkatkan keputusan pembelian konsumen, yang dimaksud dengan Keputusan pembelian adalah keputusan pengguna yang dipengaruhi oleh ekonomi, teknologi, politik, budaya, produk, harga, lokasi, promosi, bukti fizikal, orang dan proses, untuk membentuk sikap terhadap pengguna untuk memproses semua maklumat dan membuat kesimpulan berupa tindak balas yang timbul apa produk yang boleh dibeli (Alma, 2011:96).

Pendapat lain menyatakan bahwa Keputusan pembelian pengguna adalah keputusan pembelian pengguna akhir dan pengguna rumah tangga yang membeli barangan dan perkhidmatan untuk 


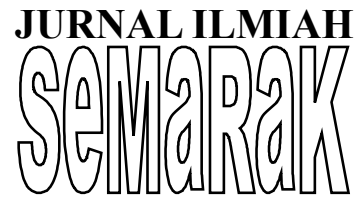

kegunaan peribadi (Kotler, 2009: 184), sedangkan menurut keputusan pembelian pengguna Tjiptono (2011:25) adalah pilihan satu atau dua pilihan alternative .

Aspek penting yang boleh mempengaruhi keputusan pembelian adalah kualiti produk, apa yang dimaksudkan dengan kualiti produk adalah keupayaan produk untuk melaksanakan fungsinya yang termasuk ketahanan, kebolehpercayaan, ketepatan, kemudahan, operasi dan pembaikan dan sifat-sifat lain. Walaupun produk tersebut berada dalam tahap toleransi yang ditetapkan, produk itu harus menjadi rekod untuk mengelakkan kesilapan yang lebih besar pada masa akan dating (Kotler dan Armstrong, 2008:272).

Aspek penting lainya yang memberi kesan kepada pengguna dalam membuat keputusan pembelian, iaitu promosi penjualan, dengan meningkatkan promosi penjualan akan mempermudah perusahaan dalam memperkenalkan produknya, Promosi jualan adalah pelbagai insentif jangka pendek untuk menggalakkan perbicaraan atau penjualan sesuatu produk atau perkhidmatan. Promosi jualan menawarkan nilai tambahan dan insentif kepada pengguna untuk melawat kedai atau membeli produk pada tempoh masa tertentu (Levy dan Weitz, 2007:433).

Aspek penting lainya yang mempengaruhi konsumen dalam melakukan keputusan pembelian yaitu celebrity endorser, yang dimaksud dengan celebrity endorser adalah satu cara untuk mempromosikan produk dengan artis sebagai pengiklan. "Semakin tinggi populariti artis, semakin ramai peminat artis itu. Promosi seperti ini adalah cara kreatif syarikat untuk menyampaikan imej positif jenama produk yang diiklankan supaya mereka dapat membentuk imej yang baik di mata pengguna.

Berdasarkan latar belakang masalah yang diterangkan di atas, penulis berminat untuk menjalankan penyelidikan "Penngaruh Product Quality, Celebrity Endorseer daan Sales Promotion terrhadap Keputuusan Pemmbelian Sepatu Adidas Pada Wilayah Tangerang Selatan.

\section{B. Rummusan Massalah}

Berdasarkan kajian latar tentang faktor - faktor yang mempengaruhi nilai buku harga yang diuraikan oleh penulis, maka rumusan masalah yang dibahas antara lain :

1. Appakah terdapart penngaruh anatara product quality terhadap keputusan pembelian?

2. Appakah terdapart penngaruh anataraa celebrity endorser terhadap keputusan pembelian?

3. Appakah terdapart penngaruh anataraa sales promotion terhadap keputusan pembelian?

4. Bagaimana pengaruh product quality, celebriity enndorser daan salles prommotion terrhadap kepputusan 5. pemmbelian?

\section{Tujuan Peneelitian}




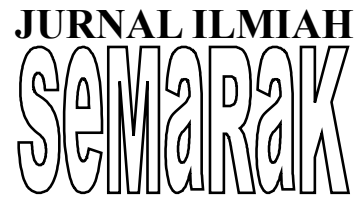

Berdasarkan dari latar belakang dan rumusan masalah dan tujuan dalam penelitian ini adalah seperti berikut :

1. Untuk meengetahui penngaruh anatara product quality terhdap kputusan pemmbelian.

2. Untuuk menngetahui penngaruh anataraa celeebrity endoorser terhadap keputusaan pemmbelian.

3. Untukk menggetahui penngaruh anataraa sales promotion terhadap keputusan pembelian.

4. Untuk mengetahui pengaruh seacara simultan antara product quality, celebriity enndorser daan salles prommotion terrhadap kepputusan pemmbelian.

\section{TINJAUAN PUSSTAKA}

\section{A. Manajemen Pemasaran}

Pemasaran adalah proses sosial di mana individu dan kumpulan mendapatkan apa yang mereka perlukan dan inginkan dengan membuat, menawarkan, dan bebas bertukar-tukar produk berharga dengan pihak lain (Kotler dan Keller, 2007:6).

Dari definisi di atas dikatakan bahawa pemasaran tidak hanya berkaitan dengan penjual dan pembeli, tetapi juga melibatkan masyarakat dan sosial. Pemasaran adalah proses perancangan dan pelaksanaan konsep, penetapan harga, mempromosikan, dan mengedarkan idea, barangan dan perkhidmatan untuk mewujudkan pertukaran yang memenuhi matlamat individu dan organisasi (Daniel dan Gates, 2001:4).
Pengurusan pemasaran adalah proses perancangan dan pelaksanaan perwujudan, penetapan harga, promosi dan pengedaran barang dan ide untuk menciptakan pertukaran dengan kelompok sasaran yang memenuhi tujuan pelanggan dan organisasi (Kotler dan Susanto, 2000:19). Manajemen pemasaran difokuskan pada penawaran perusahaan memenuhi keperluan pasaran dan keinginan, menentukan harga, mewujudkan komunikasi dan pengedaran yang berkesan untuk memberitahu, menggalakkan dan memberi perkhidmatan kepada pasaran.

Aktiviti-aktiviti pemasaran yang dijalankan oleh syarikat bertujuan untuk mengadakan pertukaran yang dikehendaki, dalam bentuk barang dan jasa atau benda lain yang dapat memenuhi kebutuhan psikologis, sosial dan budaya. Proses pertukaran boleh dilakukan oleh penjual dan pembeli, yang akan memberi manfaat kepada kedua belah pihak.

Penentuan produk, harga, promosi dan tempat untuk mencapai matlamat syarikat yang berkesan mesti disesuaikan dengan sikap dan tingkah laku pengguna, sedangkan sikap dan tingkah laku pengguna juga dipengaruhi untuk memenuhi produk syarikat.

\section{B. Pemasaran}

Aktiviti pemasaran adalah aktiviti perniagaan yang berbeza daripada aktiviti perniagaan yang lain. Dalam pengurus aktiviti pemasaran berurusan dengan 
JURNAL ILMIAH

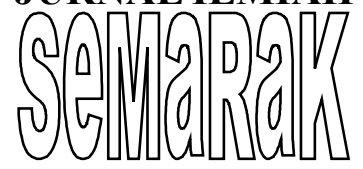

pengguna, pengguna dalaman dan pengguna luaran korporat .

Pengurus dikehendaki dapat memahami pengguna, oleh itu pengurus boleh menyediakan produk atau perkhidmatan mengikut kehendak pengguna. Bukan itu sahaja, para pengurus mesti dapat mewujudkan komunikasi yang efektif dengan pelanggan mereka mengenai produk atau perkhidmatan yang dihasilkan oleh syarikat yang mereka jalankan. Di samping itu, pengurus mesti dapat memindahkan syarikat mereka untuk menyampaikan produk atau perkhidmatan untuk dinikmati oleh pengguna. Matlamat utama semua aktiviti adalah untuk mewujudkan kepuasan pelanggan, iaitu, semua komponen yang terlibat dengan aktiviti perniagaan syarikat, supaya aktiviti-aktiviti ini dapat memberi manfaat kepada syarikat dan pemegang kepentingannya .

Pemasaran adalah salah satu aktiviti penting dan mempunyai peranan yang sangat menyumbang kepada syarikat-syarikat dalam dunia perniagaan. Aspek pemasaran adalah sangat penting untuk menyokong penciptaan sebuah syarikat yang boleh dipercayai dalam memenangi perasaan dengan syarikat lain, terutama syarikat yang sama. Oleh itu, tidak menghairankan bahawa sesebuah syarikat kini memberi tumpuan kepada aspek pemasaran sebagai usaha untuk memenuhi keperluan pengguna .
Kinnear dan Krenler (2003: 6), mentakrifkan pemasaran seperti berikut: "Pemasaran adalah suatu proses perencanaan dan pelaksanaan keputusan sebuah konsep, menetapkan harga, melakukan promosi, dan mendistribusikan ide-ide, barang-barang, dan jasa-jasa untuk menciptakan pertukaran yang dapat memuaskan tujuan individu atau tujuan organisasi .

\section{Product Quality}

Menurut Tjiptono (2008:95), produk itu adalah segala-galanya yang boleh ditawarkan oleh pengeluar untuk dipertimbangkan, diminta, dicari, dibeli, digunakan, atau dimakan oleh pasar sebagai memenuhi keperluan atau keinginan pasaran yang relevan .

Menurut Morissan (2010:75), produk pada dasarnya adalah semua perkara yang boleh dipasarkan yang dapat memuaskan pengguna apabila digunakan atau digunakan. Produk bukan sahaja objek yang boleh dilihat tetapi merupakan gabungan pelbagai faedah yang dapat memenuhi keperluan pengguna yang bukan sahaja berfungsi tetapi juga keperluan sosial dan psikologi .

Menurut Taufiq (2005:139), produk adalah apa-apa yang boleh ditawarkan ke pasaran untuk memenuhi keperluan dan keinginannya yang boleh dalam bentuk yang fisikal dan kelihatan, berat sebelah tidak ketara .

\section{Celebrity Endorser}




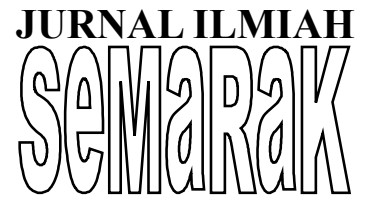

Selebriti adalah orang terkenal dalam masyarakat. Dia boleh menjadi bintang filem, bintang sinetron, model, pelawak, penyampai, ahli sukan, saintis, ahli perniagaan, ahli politik, penyanyi dan orang terkenal lain (Hsu dan McDonald, 2002: 56). Sebab untuk menggunakan selebriti sebagai bintang pengiklanan adalah kerana mereka dipercayai meningkatkan perhatian apabila rangsangan terdedah dan mengingati proses apabila pengguna mengaitkan dengan rangkaian semantik dalam ingatan (Ohanian, 1991).

Untuk membuat selebriti berkesan sebagai penyokong produk tertentu dalam iklan, ia mesti mempunyai hubungan yang bermakna atau pertandingan antara selebriti dan produk yang diiklankan oleh selebriti .

\section{E. Sales Promosi}

Promosi Menurut Swastha dan Irawan (2010:65) pada dasarnya adalah satu bentuk komunikasi pemasaran yang bertujuan untuk mendorong permintaan. Apa yang dimaksudkan dengan komunikasi pemasaran adalah aktiviti pemasaran yang bertujuan untuk menyebarkan maklumat, mempengaruhi dan atau mengingatkan pasaran sasaran syarikat dan produknya untuk bersedia menerima, membeli dan setia kepada produk atau jasa yang ditawarkan oleh syarikat yang bersangkutan .

Menurut Kotler dan Keller (2007:266) promosi jualan sebagai elemen utama dalam kempen pemasaran, adalah kumpulan insentif yang kebanyakannya jangka pendek, yang dirancang untuk merangsang pembelian produk atau perkhidmatan tertentu yang lebih cepat dan lebih besar oleh pengguna atau pedagang .

Jenis promosi penjualan menurut Perreault, Cannon, dan McCarthy (2009:371), yang ditujukan untuk pengguna atau konsumen yaitu kontes, kupon, aisle displays, sampel, pertunjukkan, point-of-purchase materials, banner dan streamers, frequent buyer programs, sponsored events. Jenis promosi penjualan yang ditujukan untuk peritel atau perantara yaitu potongan harga, promotion allowances, kontes penjualan, kalender, hadiah, pertunjukkan, pertemuan, katalog, video, dan perlengkapan barang dagang. Selain itu, jenis promosi penjualan yang ditujukan untuk karyawan atau tenaga penjual perusahaan itu sendiri yaitu kontes, bonus, pertemuan, portofolio, displays, perlengkapan penjualan, dan training materials

$$
\text { Menurut Tjiptono }
$$

Promosi Jualan adalah bentuk persuasi langsung melalui pelbagai penggunaan intensif yang dapat diatur untuk merangsang pembelian produk dengan segera dan atau menambah jumlah barang yang dibeli .

\section{F. Keputusan Pembelian}

Menurut Kotler dan Armstrong (2008:181), keputusan membeli membeli jenama yang paling disukai, tetapi dua 
faktor antara niat pembelian dan keputusan membeli. Menurut Morissan (2010: 111), keputusan pembelian adalah peringkat seterusnya setelah niat atau keinginan untuk membeli, tetapi keputusan pembelian tidak sama dengan pembelian sebenarnya .

Pada dasarnya, keputusan pembelian amat dipengaruhi oleh membeli motif yang boleh jadi kerana pembeli hanya melakukan pembelian (motivasi $=$ didorong) secara emosi, seperti kebanggaan, cadangan, dan sebagainya. Tetapi juga pembeli membeli rasional seperti harga (Daryanto, 2011:94).

Keputusan pembelian adalah keputusan pengguna yang dipengaruhi oleh ekonomi, teknologi, politik, budaya, produk, harga, lokasi, promosi, bukti fizikal, orang dan proses, untuk membentuk sikap bagi pengguna untuk memproses semua maklumat dan membuat kesimpulan dalam bentuk respons yang muncul apa produk yang boleh dibeli (Alma, 2011:96).

Menurut Kotler dan Armstrong (2008:177), jenis-jenis perilaku keputusan pembelian yaitu:

1. Tingkah laku beli kompleks (tingkah laku beli yang kompleks) ialah tingkah laku pembelian pengguna dalam keadaan yang ditentukan oleh penglibatan pengguna yang tinggi dalam pembelian dan perbezaan yang dianggap penting antara jenama.

2. Tingkah laku pembelian pengurangan Dissonance

(percanggahan mengurangkan tingkah laku belian) adalah tingkah laku belian pengguna dalam situasi yang mempunyai ciri penglibatan yang tinggi tetapi hanya ada sedikit anggapan tentang perbezaan antara jenama.

3. Kebiasaan membeli kebiasaan (tingkah laku membeli kebiasaan) adalah tingkah laku membeli pengguna dalam keadaan yang mempunyai ciri penglibatan pengguna yang rendah dan sedikit perbezaan pendapat dalam jenama.

Tingkah laku pembelian yang mencari kepelbagaian (pelbagai mencari tingkah laku beli) adalah tingkah laku pembelian pengguna yang mempunyai kelakuan penglibatan pengguna yang rendah tetapi mempunyai perbezaan jenama yang signifikan .

\section{G. Hipotesis dari Penelitian}

Hipotesis adalah suatu dugaan dalam suatu penelitian yang menjadi patokan dalam suat analisis. Adapun hipotesis yang diuji yakni sebagai berikut :

1. $\mathrm{H}_{0}$ : product quality tidak memiliki pengaruh terhadap keputusan pembelian.
$\mathrm{H}_{1}$ : product quality memiiliki pengaruh terhadap keputusan pembelian.

2. $\mathrm{H}_{0}$ : celebrity endorser tidak memiliki pengaruh terhadap keputusan pembelian.

$\mathrm{H}_{2}$ : celebrity endorser memiliki pengaruh terhadap keputusan pembelian. 


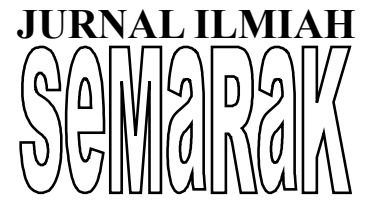

3. $\mathrm{H}_{0}$ : sales promotion tidak memiliki pengaruh terhadap keputusan pembelian.

$$
\begin{aligned}
\mathrm{H}_{3} & \text { : sales promotion memiliki } \\
& \text { pengaruh terhadap keputusan } \\
& \text { pembelian. }
\end{aligned}
$$

4. $\mathrm{H}_{0}$ : variabel product quality, celebrity endorser dan sales promotion tidak memiliki pengaruh terhadap price earning ratio.

$\mathrm{H}_{4}$ : variabel product quality, celebrity endorser dan sales promotion memiliki pengaruh terhadap price earning ratio.

\section{METODOLOGI PENELITIAN}

Lokasi dalam kajian ini adalah wilayah tangerang selatan. Kaedah yang digunakan dalam kajian ini adalah kaedah kajian kes yang merupakan satu kajian deskriptif, dengan kajian ini dijangka akan mendedahkan secara mendalam pembolehubah yang akan dapat menggambarkan analisis sifat-sifat produk, promosi dan variasi mencari penukaran merek.

Data yang digunakan menggunakan data primer dan data sekunder. Data primer dalam bentuk wawancara berganda dan dalam bentuk soal selidik sementara data sekunder dalam bentuk benda umum benda penyelidikan (sepatu adidas).

Teknik pensampelan yang akan diambil dalam kajian ini adalah kemudahan pensampelan, yang merupakan istilah umum yang merangkumi pelbagai prosedur untuk memilih responden. Pensampelan kemudahan bermaksud unit sampel yang diambil mudah untuk dihubungi, tidak menyusahkan, mudah diukur, dan koperasi. Bagi saiz sampel penyelidikan mengikut Roscoe dalam kaedah penyelidikan buku untuk perniagaan (Sugiyono, 2010:52) menyatakan bahawa saiz sampel yang boleh dilaksanakan dalam kajian adalah antara 30 dan 500. Dalam kajian ini, penyelidik menggunakan sampel sebanyak 60 responden.

Teknik pengumpulan data menggunakan temubual dan pemerhatian dan soal selidik. Sampel yang digunakan sebagai objek kajian ialah 60 orang pengguna di wilayah Tangerang Selatan.

\section{HASIIL DAAN PEMMBAHASAN}

\section{A. Analisa Objek Peenelittian}

\section{Sejarah Sepatu Adidas di Indonesia}

Adi Dassler mencipta jenama ADIDAS pada tahun 1920an; nama jenama yang bermaksud namanya namanya. Adi adalah penagih sukan, tetapi juga pengilang kasut, dan dia

mempunyai visi: mencipta kasut latihan dengan reka bentuk yang kuat dan istimewa yang akan menjadikan seorang olahragawan yang terbaik dan melindungi dia daripada kecederaan. 
Mungkin idea ini lazim di zaman moden, tetapi ia adalah pemikiran yang sangat revolusi masa (http://www.adidas.co.id/, diakses pada 10 Mac 2015).

Kasut sukan ADIDAS terbukti menjadi sangat terkenal, dalam masa yang singkat, syarikat Adi Dassler menghasilkan 100 pasang kasut sukan setiap hari yang cukup banyak untuk syarikat yang baru berkembang. Semasa akhir 1930-an, jenama ADIDAS telah membangunkan produknya; mereka mula membuat kasut sukan yang direka khusus untuk sukan tertentu. Sebagai contoh, mereka mula menghasilkan kasut tenis, kasut ais dan golf .

Pabila Adi Dassler memulakan perniagaan dengan nama ADIDAS, dia mempunyai rakan perniagaan, yang juga adiknya sendiri, Rudolph Dassler. Semasa tahun 1940-an, visi mereka tentang bagaimana syarikat itu berjalan kaki menjadi berbeza, dan pada akhirnya mereka memilih untuk mengambil jalan yang berbeza. Adi meneruskan kerja dengan kasut sukan, tetapi, saudaranya Rudolph mengasaskan sebuah syarikat yang bersaing: PUMA. Sebagai cara untuk membezakan tanda-tanda kedua-dua syarikat, Adi memutuskan untuk menambah tiga baris, ikon tidak dipertikaikan sebagai jenama ADIDAS yang sangat global .
Jenama ADIDAS benar-benar legenda. Dengan inovasi pertama kasut bola sepak, lengkap dengan kepalanya, syarikat itu telah menarik perhatian semua liga bola sepak terbesar di seluruh dunia, yang pasti terbukti sangat menguntungkan. Malah, jenama ADIDAS telah merancang kasut bola sepak yang dipakai oleh juara pada Piala Dunia 1954, yang berlaku di Switzerland. Di tengah-tengah tahun 1950-an, tepat pada tahun 1956, jenama ADIDAS menjadi penaja dari Sukan Olimpik Melbourne, sejak itu tidak ada yang menafikan, tiada apa yang dapat menghentikan perkembangan mereka. Pada masa ini, ADIDAS adalah salah satu daripada nama jenama paling terkenal di dunia, satu pencapaian yang hebat untuk permulaan yang mudah. Tidak sampai tahun 1960 Adidas mengembangkan sayapnya dan mula menghasilkan pakaian sukan. Pada tahun 1963, mereka juga mula berkembang di kawasan peralatan sukan, jika bukan untuk manuver ini, kami tidak akan melihat bola dan peralatan lain sepanjang acara sukan bola sepak utama. Secara ikonik sukan yang cantik dengan jenama ADIDAS. Sehingga kini ADIDAS telah menjadi fesyen yang sangat popular, bukan sahaja untuk sukan, tetapi juga gaya hidup

\section{Logo Adidas}

Penggunaan logo Adidas itu sendiri hanya digunakan sekitar tahun 


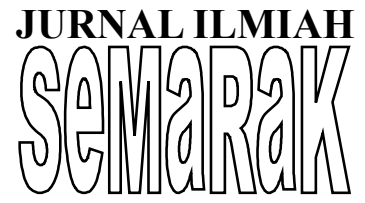

1948, ketika kedua saudaranya Dassler berpisah. Secara visual, logo Adidas hanya dalam bentuk surat Adidas, dengan nama Adolf Dassler di atas dan sebuah ilustrasi kasut di tengah. Dengan jenama ini, kasut Adi Dassler mencapai kejayaan, dengan kasut jenama Adidas diiktiraf sebagai sukan dunia seperti Sukan Olimpik Helsinki, Melbourne, Rom dan lain-lain. Dan pada masa itu pasukan bola sepak Jerman memenangi kejohanan bola sepak dunia menggunakan kasut Adidas .

Pada tahun 1972, logo Adidas telah mengalami perubahan, dengan menggunakan konsep 'Trefoil Logo', yang merupakan logo dengan tiga daun visual yang dipenuhi bersama. Konsep tiga daun ini mempunyai makna simbolik semangat Olimpik yang menghubungkan 3 benua. Sejak itu Adidas telah menjadi kasut rasmi yang digunakan dalam acara Olimpik di seluruh dunia .

Akhirnya selepas bertahuntahun kejayaan dan pengalaman kerumitan pembangunan perniagaan, pada tahun 1996, Adidas mengalami pemodenan dengan menerapkan konsep "Kita tahu - kita tahu sekarang" yang lebih menggambarkan kejayaan dan kemuliaan lalu hingga kini. Logo baru yang digunakan secara visual adalah dalam bentuk tiga rasuk slanted yang membentuk cerun yang menggambarkan kekuatan, ketahanan dan masa depan .

\section{B. Hasiil Peenemuan dann Pemmbahasan}

\section{Hasil Ujji Valliditas}

Validitas adalah ukuran yang menunjukkan sejauh mana instrumen pengukur mampu mengukur apa yang diukur. Menurut Ghozali (2011:52) uji validitas digunakan untuk mengukur sah atau valid tidaknya suatu kuesioner. Suatu kuesioner dikatakan valid jika pertanyaan pada kuesioner mampu untuk mengungkapkan sesuatu yang akan diukur oleh kusioner tersebut. Uji Validitas dilakukan dengan membandingkan nilai $r_{\text {hitung }}$ dengan $r_{\text {tabel }}$, Dengan membandingkan nilai $r_{\text {hitung }}$ dari hasil output (Corrected Item- Total Correlation) dengan $\mathrm{r}_{\text {tabel, }}$ jika $\mathrm{r}_{\text {hitung }}$ lebih besar dari $r_{\text {tabel }}$ maka butir pertanyaan tersebut adalah valid, tetapi jika $r_{\text {hitung }}$ lebih kecil dari pada $r_{\text {tabel }}$ maka butir pertanyaan tersebut tidak valid (Ghozali, 2011:54). Ditemukan nilai $r_{\text {tabel }}$ sebesar 0,468. Didapat dari jumlah kasus -2 , atau $60-2=58$, tingkat signifikansi 5\%, maka didapat $\mathrm{r}_{\text {tabel }}$ 0,254. Berikut ini adalah hasil uji validitas pada variabel penelitian (product quality, celebrity endorser, sales promotion dan keputusan pembelian):

Tabel 1 Hasil Uji Validitas 


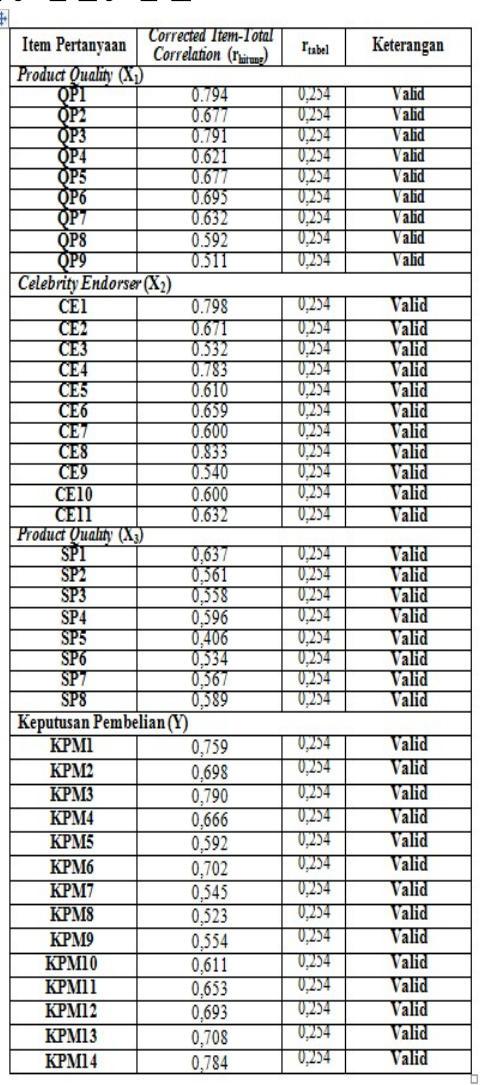

Dari hasil validitas tersebut, diperoleh data yang menyatakan bahwa dari item pertanyaan yang diberikan kepada 60 responden ditemukan nilai Corrected Item-Total Correlation $\left(\mathrm{r}_{\text {tabel }}\right)$ lebih besar dari nilai 0,254 $\left(\mathrm{r}_{\text {tabel }}\right)$ yang berarti valid maka dapat dilanjutkan ke penelitian berikutnya.

\section{Hassil Penggujian Assumsi Klassik}

\section{a. Hassil Peengujian Norrmalitas \\ Daata}

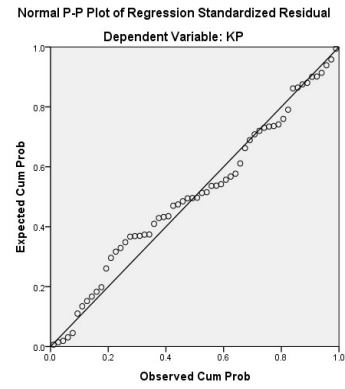

c. Hasil Uji Heteroskedastisitas

Gambar 2

Hassil Ujji Heteroskedastisitas

\section{Penngujian Noormalitas Data}

"Dari grafik di atas dapat dilihat bahwa data penelitian memiliki penyebaran dan distribusi yang normal karena data memusat pada nilai rata-rata dan median atau nilai plot PP terletak digaris diagonal, maka dapat dikatakan bahwa data tersebut berdistribusi normal"

\section{b. Hasil Ujji Multikollinearitas}

Tabel 1

Hasil Uji Multikollinearitas

\begin{tabular}{|c|c|c|c|}
\hline \multicolumn{4}{|c|}{ Coefficients ${ }^{*}$} \\
\hline \multirow{2}{*}{\multicolumn{2}{|c|}{ Model }} & \multicolumn{2}{|c|}{ Collinesrity Statistics } \\
\hline & & Tolergnce & VIF \\
\hline \multirow{4}{*}{1} & (Constant) & & \\
\hline & $Q P$ & .317 & 3.151 \\
\hline & $\mathrm{CE}$ & .238 & 4.209 \\
\hline & SP & 298 & 3.352 \\
\hline
\end{tabular}

"Berdasarkan pada tabel di atas terlihat bahwa nilai Tolerance tidak kurang dari 0,1 dan nilai Varian Inflation Factor (VIF) tidak lebih dari 10, analisis ini dapat disimpulkan bahwa model regresi linier berganda terbebas dari asumsi klasik maka variabel dapat digunakan dalam penelitian”.

Gambar 1 
Jurnal Semarak,Vol. 2,No.2, Juni 2019, Hal (51- 65)

@Prodi Manajemen Fakultas Ekonomi Universitas Pamulang

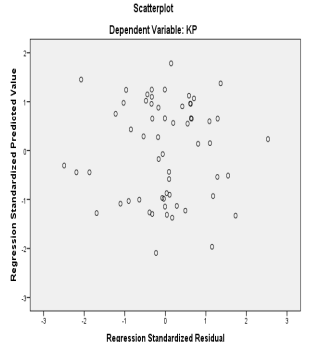

"Hasil pengolahan data di atas bahwa terlihat titik-titik menyebar di atas dan di bawah angka nol pada sumbu $\mathrm{Y}$ dan tidak terlihat pola tertentu. Dengan demikian pada persamaan regresi linier berganda dalam model ini tidak ada gejala atau tidak ada heteroskedastisitas".

\section{Hassil Koeefisien Reegresi Liinier}

\section{Beerganda}

\section{a. Haasil Koeefisien Addjusted $\boldsymbol{R}^{2}$}

\section{Tabel 3}

Hassil Kooefisien Adjjusted $\mathbf{R}^{2}$

\begin{tabular}{|l|c|r|r|r|r|}
\hline Model & $R$ & R Square & $\begin{array}{l}\text { Adjusted } \\
\text { R Square }\end{array}$ & $\begin{array}{r}\text { Std. Error of } \\
\text { the Estimate }\end{array}$ & Durbin-Watson \\
\hline 1 & $.914^{3}$ & .836 & .827 & .21733 & 2.442 \\
\hline a. Predictors: (Constant), SP, QP, CE \\
\hline b. DependentVariable:KP
\end{tabular}

"Berdasarkan kepada tabel di atas diketahui nilai Adjusted $R$ square sebesar 0,827 (82,7\%), Ini menunjukkan bahwa dengan menggunakan model regresi yang didapatkan dimana variabel independen yaitu quality product, celebrity endorser dan sales promotion memiliki pengaruh terhadap variabel keputusan pembelian sebesar $82,7 \%$.

Sedangkan sisanya $17,3 \%$ dijelaskan dengan faktor atau variabel lain yang tidak diketahui dan tidak termasuk dalam analisis regresi ini, seperti harga, kualitas pelayanan dan lain-lain".

\section{b. Hasil Koefisien Perrsamaan} Regressi Liniier Bergaanda

"Analisis regresi linier berganda ialah ujian yang digunakan untuk menentukan sejauh mana tahap pengaruh antara pembolehubah bebas (quality product, celebrity endorser dan sales promotion) ke atas pembolehubah bergantung (keputusan pembelian). Hasil daripada pengaruh regresi linear berganda bagi poduct quality, celebrity endorser dan sales promotion terhadap keputusan pembelian adalah seperti berikut:

Tabel 4

Koefiisien Persamaan Regresi Pelbagai Linear

\begin{tabular}{|c|c|c|c|c|c|c|c|c|}
\hline \multicolumn{9}{|c|}{ Coefficients $^{\mathrm{S}}$} \\
\hline \multirow[t]{2}{*}{ Mode } & & \multicolumn{2}{|c|}{$\begin{array}{l}\text { Unstandardized } \\
\text { Coefficients }\end{array}$} & \multirow{2}{*}{$\begin{array}{c}\text { Standardized } \\
\text { Coefficients } \\
\text { Beta }\end{array}$} & \multirow[t]{2}{*}{$t$} & \multirow[t]{2}{*}{ Sig. } & \multicolumn{2}{|c|}{$\begin{array}{l}\text { Collinearity } \\
\text { Statistics }\end{array}$} \\
\hline & & $B$ & Stol. Error & & & & Tolerance & VIF \\
\hline \multirow{4}{*}{1} & (Constant) & .117 & .253 & & .464 & .645 & & \\
\hline & $Q P$ & .424 & .094 & .433 & 4.501 & .000 & 317 & 3.151 \\
\hline & $C E$ & .440 & .109 & .447 & 4.023 & .000 & .238 & 4.209 \\
\hline & SP & .100 & . 110 & .090 & .907 & .028 & .298 & 3.352 \\
\hline
\end{tabular}

"Jadual di atas boleh dirumuskan persamaan regresi untuk menentukan product quality, celebrity endorser dan sales promotion seperti berikut":

$$
\begin{aligned}
\mathrm{Y}= & \mathrm{a}+\mathrm{bx}_{1}+\mathrm{bx}_{2}+\mathrm{bx}_{3}+\mathrm{bx} \\
\mathrm{Y}= & 0,117+0,424 \mathrm{X}_{1}+0,440 \mathrm{X}_{2}+ \\
& 0,100 \mathrm{X}_{3}
\end{aligned}
$$




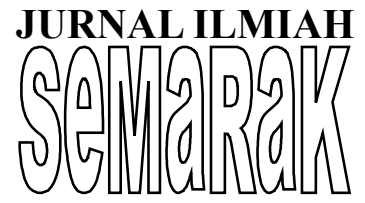

Keterangan:

Y : Keputusan pembelian

$\mathrm{X}_{1}$ : product quality

$\mathrm{X}_{2}$ : celebrity endorser

$\mathrm{X}_{3}$ : sales promotion

"Koefisien persamaan regresi linear berganda di atas boleh ditafsirkan sebagai pekali regresi malar 0,117 yang menunjukkan bahawa jika product quality, celebrity endorser dan sales promotion adalah sifar (konstan), maka keputusan pembelian akan naik sebesar 0.117 unit. Perhatikan bahawa pembolehubah lain dianggap malar". "Pelbagai pemboleh ubah menetapkan 0.424 menunjukkan bahawa jika pemboleh product quality meningkat sebanyak 1 unit, ia akan meningkatkan keputusan pembelian sebanyak 0,424 unit". "celebrity endorser sebesar 0,440 menunjukkan bahawa jika pembolehubah celebrity endorser meningkat sebanyak 1 unit, ia akan meningkatkan keputusan pembelian sebanyak 0,440 unit". "Pembolehubah sales promotion sebanyak $\quad 0,100$ menunjukkan bahawa jika pulangan atas vaiabel sales promotion meningkat sebanyak 1 unit, ia akan meningkatkan keputusan pembelian sebanyak 0,100 unit, dengan syarat bahawa pembolehubah lain dianggap tetap"

\section{Uji Hipotesis}

\section{a. Uji Statistik F (Simultan)}

"Ujian F dilakukan untuk melihat kesan product quality, celebrity endorser dan sales promotion pada pembolehubah kepuutusan pembelian. Berikut adalah keputusan ujian serentak, keputusan ujian ANOVA diperolehi seperti berikut":

Tabel 5

Hasil Uji Statistik F (Simultan)

\begin{tabular}{|c|c|c|c|c|c|c|}
\hline \multicolumn{7}{|c|}{ ANOVA } \\
\hline Model & & Sum of Squares & df & Mean Square & $\bar{F}$ & Sig. \\
\hline \multirow{3}{*}{1} & Regression & $\begin{array}{r}13.437 \\
\end{array}$ & 3 & 4.479 & 94.831 & $.000^{\circ}$ \\
\hline & Residual & 2.645 & 56 & .047 & & \\
\hline & Total & 16.083 & 59 & & & \\
\hline
\end{tabular}

Daripada data di atas memperoleh nilai signifikan 0,000 bermakna bahawa peruntukan nombor dua terpakai dalam kajian ini yang Ho ditolak dan Ha diterima. Keputusan ujian $\mathrm{F}$ ini menyatakan bahawa keputusan ujian serentak di atas adalah benar.

Dalam kajian ini, nilai $F$ yang dikira daripada 94,831 adalah lebih tinggi daripada nilai $\mathrm{F}_{\text {table }} \quad 2,77$. Boleh disimpulkan bahawa terdapat kesan linear antara pembolehubah

b. Uji t (Uji Secara Parsial)

Tabel 6

Ujji t (Uji Secara Parsial) 

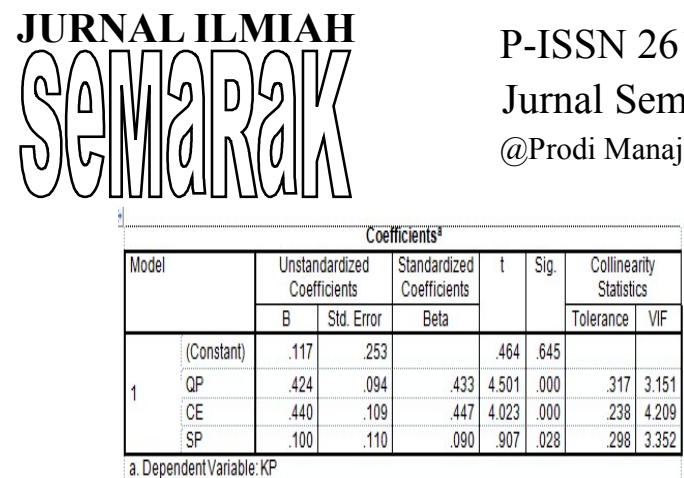

"Berdasarkan keputusan ujian t, didapati bahawa variabel bebas (product quality, celebrity endorser dan sales promotion) mempunyai kesan separa pada keputusn pembelian".

\section{KESIMPULAN DAN SARAN}

\section{A. Kesimpulan}

Kajian ini dijalankan untuk menentukan kesan product quality, celebrity endorser dan sales promotion. Berdasarkan hasil penyelidikan yang dijelaskan dalam bab sebelumnya, beberapa kesimpulan dapat diambil seperti berikut:

1. Hasil kajian menyatakan bahawa sebahagian atau berdasarkan keputusan ujian $t$ menunjukkan bahawa pemboleh product quality yang berpotensi pelaburan mempengaruhi keputusan pembelian.

2. Hasil kajian menyatakan bahawa sebahagian atau berdasarkan hasil uji $\mathrm{t}$ menunjukkan bahawa celebrity endorser mempengaruhi keputusan pembelian.

3. Hasil kajian menyatakan bahawa sebahagian atau berdasarkan hasil ujian $\mathrm{t}$ menunjukkan bahawa sales promotion mempengaruhi keputusan pembelian.

4. Hasil kajian menyatakan bahawa secara serentak atau berdasarkan keputusan ujian $\mathrm{F}$ menunjukkan terdapat pengaruh yang signifikan antara product quality, celebrity endorser dan sales promotion terhadap keputusan pembelian.

\section{B. Saran}

Hasil kajian ingin memberikan beberapa cadangan yang dapat disampaikan, iaitu:

1. Sebaiknya perusahaan lebih meningkatkan product quality dengan meningkatkan pengecekan barang dalam meningkatkan kualitas produk.

2. Sebaiknya perusahaan lebih baik lagi dalam memilih celebrity endorser sesuai dengan tipe produk.

3. Sebaiknya perusahaan lebih meningkatkan sales promotion dengan meningkatkan promosi dengan mengadakan event-event.

\section{DAFTAR PUSTAKA}

Alma, Buchari. 2011. "Manajemen Pemasaran dan Pemasaran Jasa”. Penerbit Alfabeta. Bandung.

Arifin, Zainal. 2009. Dampak Store Atmosphere Terhadap Keputusan Pembelian. Fakultas Ilmu Administrasi Unibraw. Malang.

Barsky, Keki R. 2000. “Beyond Customer Satisfaction to Customer Loyalty. AMA Management Briefing, New York. 


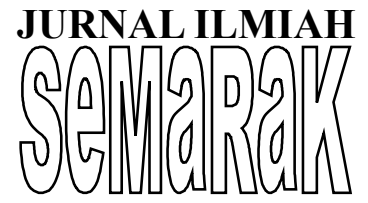

Berman, Barry dan Evans, Joel R. 2004. Retail Management A Strategic Apporoach. Ninth Editon. New Jersey.

Berman, Barry dan Evans, Joel. 1997. "Marketing", Seventh edition, Prentice Hall. Inc. New Jersey.

Cannon, Perreault dan McCarthy. 2009. Pemasaran Dasar Pendekatan Manajerial Global Buku 2 Edisi 16. Salemba Empat, Jakarta.

Chandra, Handi. 2008. "Marketing untuk Orang Awam”. Maxicom. Palembang

Dessyana. 2013. "Store Atmosphere Pengaruhnya Terhadap Keputusan Pembelian Konsumen Di Texas Chicken Multimart Ii Manado". ISSN 2303-1174. Manado

Fuad. 2010. "Store Atmosphere Dan Perilaku Pembelian Konsumen Di Toko Buku Gramedia Malang”. Jurnal Manajemen. Malang.

Ghozali, Imam. 2011. "Aplikasi Analisis Multivariate dengan Program IBM SPSS 19. Edisi 5". Badan Penerbit Universitas Diponegoro. Semarang.

Hamid, Abdul. 2010. "Panduan Penulisan Skripsi”. FEIS UIN Syarif Hidayatullah. Jakarta.

Handi Chandra. 2008. "Marketing UntukOrang Awam”. Maxilon. Palembang.

Herdiani. 2010. "Pengaruh Celebrity Endorser, Citra Merk Rabbani Terhadap Keputusan Pembelian Konsumen (Studi kasus dilakukan di Rabbani Tasikmalaya)”. Jurnal Manajemen. Tasikmalaya.
Pasaribu, V. L. D. P. D. (2018). PENGARUH BIAYA PROMOSI TERHADAP
PENINGKATAN KARTU FLEXI PT. TELEKOMUNIKASI SELULER (TELKOMSEL) JAKARTA (Studi kasus Produk Kartu Flexi Pt. Telkomsel. Jakarta Selatan). JURNAL PEMASARAN KOMPETITIF, 1(2).

Pasaribu, V. L. D. (2018). ANALISIS PENGARUH PROMOSI, KUALITAS PRODUK DAN DESAIN KEMASAN TERHADAP KEPUTUSAN PEMBELIAN HAND AND BODY LOTION MEREK CITRA (Studi Kasus Carrefour Pamulang, Tangerang Selatan). JURNAL PEMASARAN KOMPETITIF, 1(4). 